\title{
Human cDNAs encoding homologs of the small p34Cdc28/Cdc2-associated protein of Saccharomyces cerevisiae and Schizosaccharomyces pombe
}

\author{
Helena E. Richardson, Constance S. Stueland, Julian Thomas, Paul Russell, and Steven I. Reed \\ Department of Molecular Biology, Research Institute of Scripps Clinic, La Jolla, California 92037 USA
}

The Cks1 protein is a component of the Cdc28 protein kinase in the budding yeast Saccharomyces cerevisiae. This paper reports the cloning of two homologs of the $S$. cerevisiae CKS1 gene from human cells. These homologs, CKShs1 and CKShs2, both encode proteins of 79 amino acids that share considerable homology at the amino acid level with the products of CKS1 from S. cerevisiae and suc1+ from the fission yeast

Schizosaccharomyces pombe. Both human homologs are capable of rescuing a null mutation of the $S$. cerevisiae CKS1 gene when expressed from the $S$. cerevisiae GAL1 promoter. S. pombe suc1 ${ }^{+}$expressed from the GAL1 promoter is also capable of rescuing a $S$. cerevisiae cks1 null mutation. Ckshs1 or Ckshs2 protein linked to Sepharose beads can bind the $\mathrm{Cdc28} / \mathrm{Cdc2}$ protein kinase from both $S$. cerevisiae and human cells. The CKShs1 and CKShs2 mRNAs are expressed in different patterns through the cell cycle in HeLa cells, which may reflect specialized roles for the encoded proteins.

[Key Words: Cell cycle; suc1+ ${ }^{+}$CKS1; p13; HeLa cells]

Received March 29, 1990; revised version accepted May 22, 1990.

Considerable progress has been made recently in understanding the molecular mechanisms that operate in eukaryotic cells to control entry into the cell cycle $\left(\mathrm{G}_{1}-\right.$ to S-phase transition) and entry into mitosis $\left(\mathrm{G}_{2}-\right.$ to $\mathrm{M}$ phase transition). Of particular importance is the finding that many of the components involved in these control points are conserved in a wide range of eukaryotes from yeasts to humans (for review, see Cross et al. 1989; Hunt 1989; Murray and Kirschner 1989a; O'Farrell et al. 1989; Pardee 1989; Smith 1989). One of these conserved proteins, the $\mathrm{Cdc} 28 / \mathrm{Cdc} 2$ protein kinase, plays a central role in cell-division control in eukaryotic cells. The Cdc28/Cdc2 protein kinase was discovered first in the budding yeast Saccharomyces cerevisiae (Hartwell et al. 1974; Reed 1980; Lorincz and Reed 1984; Reed et al. 1985) and the fission yeast Schizosaccharomyces pombe (Nurse and Bissett 1981; Beach et al. 1982; Hindley and Phear 1984; Simanis and Nurse 1986) and was subsequently identified in humans (Draetta et al. 1987; Lee and Nurse 1987), Xenopus (Dunphy et al. 1988; Gautier et al. 1988), starfish (Labbe et al. 1988), mouse (Lee et al. 1988; Cisek and Corden 1989), chicken (Krek and Nigg 1989), and plant cells (John et al. 1989). In S. pombe the Cdc2 protein kinase has been shown to play a central role in both $G_{1}$ and $G_{2}$ control points (Nurse and Bissett 1981). In $S$. cerevisiae the $\mathrm{G}_{1}$ role of the $\mathrm{Cdc} 28$ protein

\footnotetext{
${ }^{1}$ Corresponding author.
}

kinase has been studied extensively (Reed 1980; Mendenhall et al. 1987, 1988; Wittenberg and Reed 1988), and $a \mathrm{G}_{2}$ role has also been demonstrated recently (Reed and Wittenberg 1990). In higher eukaryotes an essential role for the $\mathrm{Cdc} 2 / \mathrm{Cdc} 28$ kinase activity has as yet only been demonstrated at the $G_{2}$ to $M$ phase of the cell cycle (Riabowol et al. 1989). However, in the absence of genetic analysis, a $G_{1}$ role in somatic cells cannot be excluded.

Recently, a connection has been established between the $\mathrm{Cdc} 2 / \mathrm{Cdc} 28$ protein kinase and maturation promoting factor (MPF), an activity initially described in mature Xenopus oocytes which, when injected into immature oocytes, induces them to undergo meiotic maturation (Masui and Markert 1971; Reynhout and Smith 1974). MPF has been purified from Xenopus and starfish oocytes and has been shown to contain, as an essential component, the $\mathrm{Cdc} 2 / \mathrm{Cdc} 28$ protein kinase /Gautier et al. 1988; Lohka et al. 1988; Labbe et al. 1989a). It also appears that an activity known as growth-associated histone $\mathrm{Hl}$ kinase, which is present during mitosis in a number of organisms (Bradbury et al. 1974; Chambers et al. 1983/, contains the Cdc2/Cdc28 protein and is likely to be identical to MPF (Arion et al. 1988; Labbe et al. 1988, 1989a; Brizuela et al. 1989; Draetta et al. 1989; Langan et al. 1989).

It has been demonstrated in several systems that the active form of $\mathrm{Cdc} 2 / \mathrm{Cdc} 28$ protein kinase exists as a 
multimeric complex with other proteins (Brizuela et al. 1987, 1989; Draetta et al. 1987, 1989; Arion et al. 1988; Draetta and Beach 1988; Gautier et al. 1988, 1990; Wittenberg and Reed 1988; Labbe et al. 1989b; Meijer et al. 1989; Pondaven et al. 1990). One of the proteins that associates with $\mathrm{Cdc} 2 / \mathrm{Cdc} 28$ has been identified as cyclin (Booher et al. 1989; Draetta et al. 1989; Labbe et al. 1989b; Meijer et al. 1989; Pines and Hunter 1989; Gautier et al. 1990). Cyclins were first described in oocytes of marine invertebrates as proteins that change dramatically in abundance throughout the cell cycle, reaching maximal levels just before the onset of mitosis (Rosenthal et al. 1980; Evans et al. 1983; Pines and Hunt 1987; Standart et al. 1987; Westendorf et al. 1989). Cyclins have subsequently been identified in Drosophila (Lehner and O'Farrell 1989; Whitfield et al. 1989), Xenopus (Minshull et al. 1989), humans (Pines and Hunter 1989), and the fission yeast S. pombe (Booher and Beach 1988; Goebl and Byers 1988; Hagan et al. 1988; Solomon et al. 1988). These cyclins are presumed activators of the $\mathrm{Cdc} 28 / \mathrm{Cdc} 2$ protein kinase in the $\mathrm{G}_{2}$ to M-phase transition (Swenson et al. 1986; Booher and Beach 1987, 1988; Booher et al. 1989; Lehner and O'Farrell 1989; Minshull et al. 1989; Murray and Kirschner 1989b; Murray et al. 1989). Recently, a second class of cyclins, the $G_{1}$-specific cyclins, involved in activation of $\mathrm{Cdc} 28 / \mathrm{Cdc} 2$ kinase in the $\mathrm{G}_{1^{-}}$to $S$-phase transition, have been identified in the budding yeast $S$. cerevisiae (Cross 1988; Nash et al. 1988; Hadwiger et al. 1989b; Richardson et al. 1989; Wittenberg et al. 1990).

Another protein that interacts with $\mathrm{Cdc} 2 / \mathrm{Cdc} 28$ is the product of the $S$. pombe suc1 ${ }^{+}$gene $(\mathrm{p} 13)$ or the $S$. cerevisiae CKS1 gene (p18). The $S$. pombe suc1+ gene was isolated as a high-copy suppressor of temperature-sensitive mutations in $c d c 2$ (Hayles et al. 1986b). CKS1 was isolated from $S$. cerevisiae by a similar procedure (Hadwiger et al. 1989a) and encodes a protein highly related at the amino acid level to the $S$. pombe suc1 $1^{+}$gene product. In $S$. pombe the suc1 ${ }^{+}$gene product has been shown by genetic and biochemical approaches to interact with Cdc2 (Hayles et al. 1986a,b; Brizuela et al. 1987; Hindley et al. 1987; Moreno et al. 1989). Likewise, in $S$. cerevisiae the Cksl protein has been demonstrated to interact with Cdc28 (Hadwiger et al. 1989a). A homolog of Cks1/Sucl has been reported to exist in human cells (Draetta et al. 1987; Draetta and Beach 1988; Bailly et al. 1989; Riabowol et al. 1989).

The precise role of Cksl/Sucl in the control of the cell cycle is not clear. There has been an accumulation of conflicting data based on work with fission yeast, budding yeast and vertebrates (Hayles et al. 1986a; Hindley et al. 1987; Dunphy et al. 1988; Dunphy and Newport 1989; Hadwiger et al. 1989a; Moreno et al. 1989; Riabowol et al. 1989; S.I. Reed, unpubl.). Whether the apparent discrepancies concerning the role(s) of CKS1/suc1 result from fundamental differences or simply reflect differences in experimental design, will require additional study in these organisms and in other systems. Therefore, to investigate further the role of the Cks1/ Sucl homologs in the cell cycle, we chose to use a dif- ferent system, that of somatic vertebrate cells. As a first step, we cloned two cDNAs encoding Cksl/Sucl homologs from human cells. These cDNAs are capable of rescuing a null mutation in the endogenous $S$. cerevisiae CKS1 gene. We show that both human Cks1/Sucl homologs can bind the $\mathrm{Cdc} 2 / \mathrm{Cdc} 28$ protein kinase complex in vitro and present data on the expression patterns of the corresponding mRNAs through the cell cycle in HeLa cells.

\section{Results}

\section{Cloning CKS1 homologs from human cells}

$C K S 1$ from $S$. cerevisiae and suc1 ${ }^{+}$from $S$. pombe are $67 \%$ identical at the amino acid level (Hadwiger et al. 1989a). By comparison of the amino acid sequences of these proteins, two degenerate oligonucleotides were designed that could be used in the polymerase chain reaction (PCR) (C. Lee et al. 1988; Saiki et al. 1988) to amplify a region of $198 \mathrm{bp}$ from the $S$. cerevisiae CKS1 gene and from an intronless version of the $S$. pombe suc1 ${ }^{+}$ gene (obtained from J. Hayles and P. Nurse). The $5^{\prime}$ oligonucleotide was derived from the peptide sequence DD(NE)YEYRHVM and was 8000-fold degenerate, whereas the $3^{\prime}$ oligonucleotide was derived from the peptide sequence PEPHILLFK and was 33,000-fold degenerate (see Fig. 2, below). Synthetic restriction sites were placed at the $5^{\prime}$ ends of these degenerate oligonucleotides so that the PCR products could be cloned easily, and the DNA sequence could be determined.

The degenerate oligonucleotides were used in the PCR to amplify DNA from a HeLa cell cDNA library and from $S$. cerevisiae and $S$. pombe genomic libraries as controls. Bands of the predicted molecular weight were obtained from the $S$. cerevisiae and $S$. pombe genomic DNA libaries. Two bands in the range of 150-200 bp were obtained from the human cDNA library. These PCR products were cloned, and DNA sequence analysis revealed three distinct clones. The first two contained an open reading frame (ORF) showing extensive amino acid sequence homology to the $S$. cerevisiae CKS1 and $S$. pombe suc1 ${ }^{+}$genes. These clones were named CKShs1

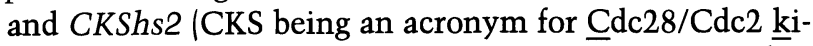
nase subunit). The third did not contain an ORF that extended from the amino- to carboxy-terminal primers and showed no homology to the yeast CKS1 and suc1 ${ }^{+}$ genes; therefore, it was not pursued further.

The PCR clones of the human CKS1 homologs were used to probe HeLa cell cDNA libraries to obtain fulllength cDNA clones (see Experimental procedures). DNA sequence analysis of these clones revealed that CKShs 1 and CKShs2 are very similar (Fig. 1). The largest CKShs2 clones contained a 612-bp insert with an ORF that is predicted to encode a 79-amino-acid protein and has a $3^{\prime}$-untranslated region of $280 \mathrm{bp}$ before the poly(A) segment. The largest CKShs1 contained a 717-bp insert with an ORF that potentially encodes a protein of 79 amino acids and has a $3^{\prime}$-untranslated region of $470 \mathrm{bp}$. The CKShs1 clones obtained did not contain a poly(A) 
A

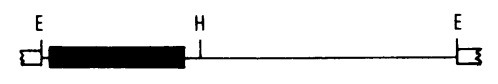

$100 \mathrm{bp}$

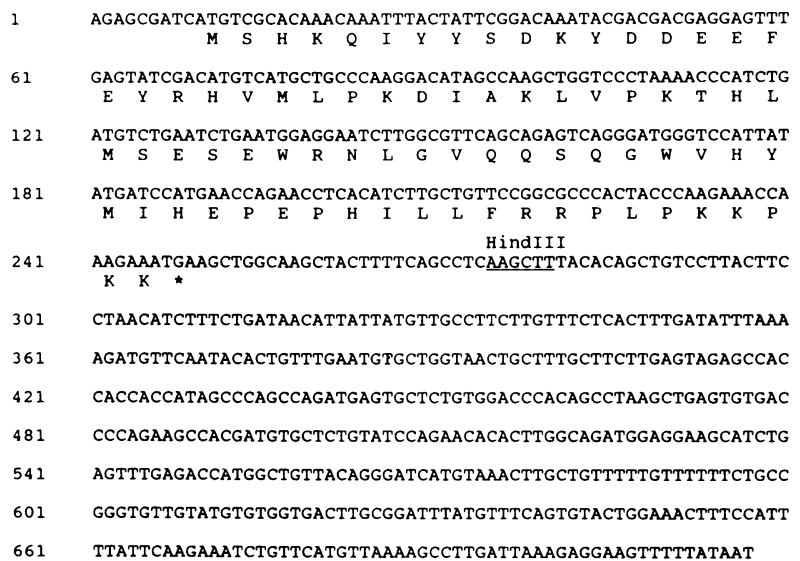

B

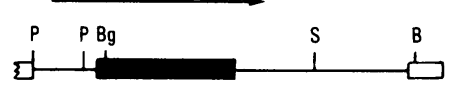

$100 \mathrm{bp}$

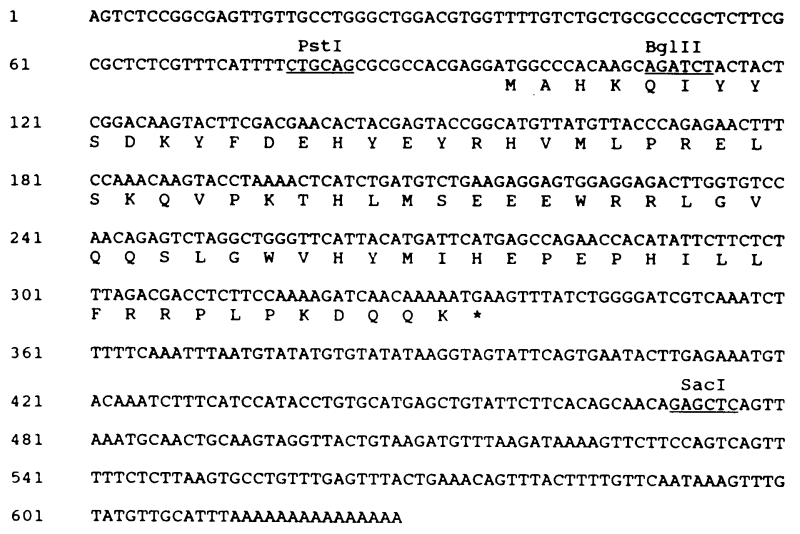

Figure 1. (A) DNA sequence of $C K S h s 1$ and $(B) C K S h s 2$ cDNA clones. The cDNA clones are diagrammatically represented in bar figures. Plasmid regions are represented by open boxes. The ORFs are indicated by shaded boxed regions. For cloning the cDNA, poly $(\mathrm{G} / \mathrm{C})$ or poly $(\mathrm{A} / \mathrm{T})$ regions immediately preceding and following the two $E c o R I$ sites, respectively $(A)$ and immediately preceding the $P$ stI site $(B)$ were used. Relevant restriction sites are indicated: (B) BamHI; (Bg) BgIII; (E) EcoRI; (H) HindIII; (P) PstI; (S) SacI. The DNA sequences of the cDNAs and the predicted amino acid sequence are shown below with relevant restriction sites. Arrows indicate direction of transcription.

tail (see Experimental procedures); thus, the 3 '-untranslated region may be longer than $470 \mathrm{bp}$. The predicted start sites for both human CKS cDNAs have the conserved A at -3 , but only CKShs2 has the conserved G at +4 (Kozak 1981).

Figure 2 shows an alignment of the two human Cks1 homologs with $S$. cerevisiae Cksl and S. pombe Sucl. The predicted Ckshs1 and Ckshs2 proteins (79 amino acids) are considerably smaller than their homologs from
S. cerevisiae ( 150 amino acids) and S. pombe (113 amino acids). Compared with the yeast homologs, the human Cks1 homologs contain truncations at both the amino and carboxyl termini and also have a region of 9 amino acids deleted in the middle of the protein. Ckshs1 and Ckshs2 are highly related proteins containing 64 of 79 identical amino acids $(81 \%$ identity). Ckshs1 shares $53 \%$ identity with both Cks1 and Suc1, and Ckshs2 shares $57 \%$ identity with each of the yeast homologs.

\section{Human CKS1 homologs rescue an S. cerevisiae CKS1 null mutation}

Although the human Cksl homologs share a high level of homology with the yeast Cksl and Sucl proteins, they are predicted to encode considerably smaller proteins. For this reason it was important to determine whether CKShs1 and CKShs2 are functional homologs of the yeast genes, by testing whether they are able to replace the S. cerevisiae CKS1 gene to allow normal growth of cells. To allow expression of the human cDNAs in S. cerevisiae, CKShs 1 and CKShs2 were placed under the control of the $S$. cerevisiae GAL1 promoter in the plasmid YCpG2 (CEN1, LEU2, URA3, pGAL1; see Experimental procedures). The GAL1 promoter is strongly induced by galactose and repressed by glucose (Johnston and Davis 1984). Thus, expression of the human CKS1 homologs could be controlled by growing cells in galactose or glucose media. As controls, an intronless version of the $S$. pombe suc1 $1^{+}$gene and the $S$. cerevisiae CKS1 gene were placed under control of the GAL1 promoter in YCpG2 (see Experimental procedures).

These plasmids were used to transform a $S$. cerevisiae haploid strain containing a null mutation in CKS1 made by insertion of LEU2 near the $5^{\prime}$ end of the gene (cks1 :: LEU2) but carrying a plasmid copy of the CKS1 gene (CEN1, TRP1, CKS1). Transformants of this strain with the YCpG2[CKS1 homolog] plasmids were selected on plates lacking uracil and containing glucose (noninducing conditions). To test whether expression of the human CKS1 homologs under GAL1 promoter control were able to replace the $S$. cerevisiae CKS1 gene, the cells were cured of the plasmid containing the wild-type CKS1 gene while expression of the human genes from the GAL1 promoter was allowed, as follows. Cells were grown for several generations on plates containing tryptophan (to allow loss of the plasmid carrying the wildtype $C K S 1$ gene and the TRP1 marker) and galactose (to allow expression of the CKS1 homolog from the GAL1 promoter). Loss of the plasmid containing the wild-type CKS1 gene was monitored by testing colonies for tryptophan auxotrophy.

By using this approach on the control plasmids, it was found that the plasmid containing the wild-type CKS1 gene could be lost from cells containing the plasmids YCpG2[CKS1] or YCpG2[suc1 ${ }^{+}$] but not from cells containing a plasmid with the $C K S 1$ gene in the reverse orientation (YCpG2[CKS1rev]). The ability of the expression of suc1 $1^{+}$from the GAL1 promoter to allow loss of the plasmid containing the wild-type CKS1 gene indi- 

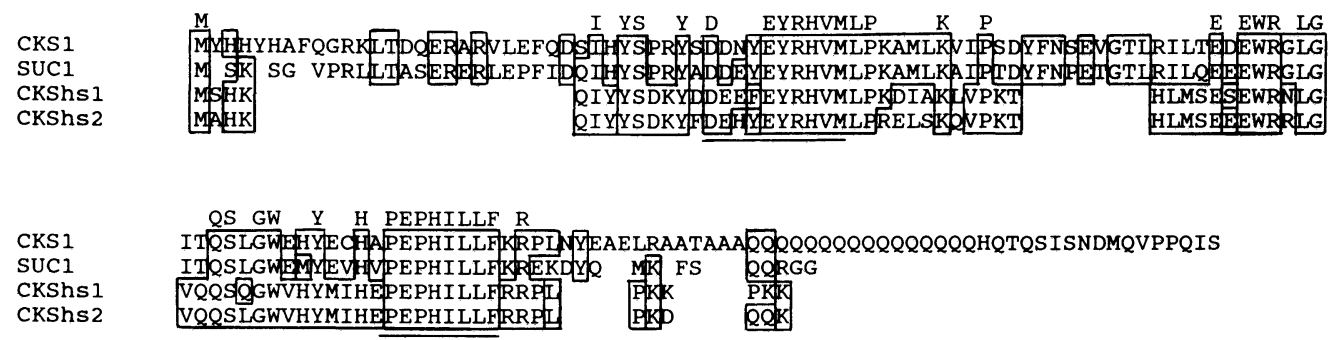

Figure 2. Alignment of the CKShs1 and CKShs2 amino acid sequence with $S$. cerevisiae Cks1 and S. pombe Sucl. Identical amino acids between Ckshs1 or Ckshs2 and the yeast Cks1 homologs are boxed. Amino acids that are conserved between all four homologs are indicated above the Cksl sequence. The regions used to generate degenerate primers for PCR are underscored.

cates that $S$. pombe suc1 $1^{+}$is indeed a functional homolog of $S$. cerevisiae CKS1. As shown in Figure 3A-C, cells containing YCpG2[CKS1] or YCpG2[suc1 ${ }^{+}$] grown in galactose medium are slightly larger than wild-type $C K S 1^{+}$cells /which may be due to the overexpression of the CKS1 homologs from the GAL1 promoter, as will be discussed below). However, after several generations of growth in glucose medium, these cells become grossly enlarged and abnormally shaped and stop dividing (as in Fig. 3F).

When cells containing YCpG2[CKShs1] or YCpG2[CKShs2] and the wild-type CKS1 plasmid were grown in galactose medium containing tryptophan, Trp- colonies (cured of the CEN1-CKS1-TRP1 plasmid) were obtained at a frequency similar to that with YCpG2[CKS1] (20-30\% after 20 generations of nonselective growth). This result indicates that CKShs1 and CKShs2 can replace the $S$. cerevisiae CKS1 gene to allow cell growth and thus verifies that the human CKS gene products are indeed functional homologs of $S$. cerevisiae CKS1.

In galactose medium, cells containing YCpG2[CKShs1] or YCpG2[CKShs2] exhibit an enlarged morphology (Fig. 3D,E). The cells actually appear slightly larger than the equivalent cells expressing the yeast CKS1 homologs from the GAL1 promoter (Fig. 3B,C). This may be due to the inability of the human CKS homologs to fully rescue the $S$. cerevisiae CKS1 null mutation or to the overexpression of the heterologous proteins resulting in a delay in the cell cycle. The relative abilities of the human and yeast $C K S 1$ homologs to support growth of the cks1- cells were analyzed by determining their growth rates in galactose medium and after shifting the cells to glucose medium (where transcription of the CKS1 homologs from the GAL1 promoter is repressed). In galactose medium, cells expressing the human CKS1 homologs showed similar growth rates to those expressing the yeast homologs (approximately one doubling every 5-6 hr). This suggests that the human CKS1 homologs and the $S$. pombe suc1 ${ }^{+}$gene expressed from the GAL1 promoter are equally capable of allowing cell-cycle progression as the $S$. cerevisiae CKS1 gene expressed from the GAL1 promoter. When cells carrying YCpG2[CKShs1] or YCpG2[CKShs2] are shifted to glucose medium (Fig. 4), they are capable of undergoing $\sim 6$ doublings before arresting as large aberrantly shaped cells, many of which showed a $G_{1}$-arrest morphology (large unbudded cells; Fig. 3F). Large budded cells were also present (Fig. 3F), and experiments are in progress to determine whether $C K S 1$ plays a role in the $\mathrm{G}_{2^{-}}$to $\mathrm{M}$ phase transition of $S$. cerevisiae. Cells carrying YCpG2[CKS1] or YCpG2[suc1 ${ }^{+}$] shifted to glucose medium allow $\sim 8$ and 13 rounds of division, respectively (data not shown). Thus, Cks1 and its three homologs are extremely stable proteins that can persist in functional form long after their synthesis has been terminated. The
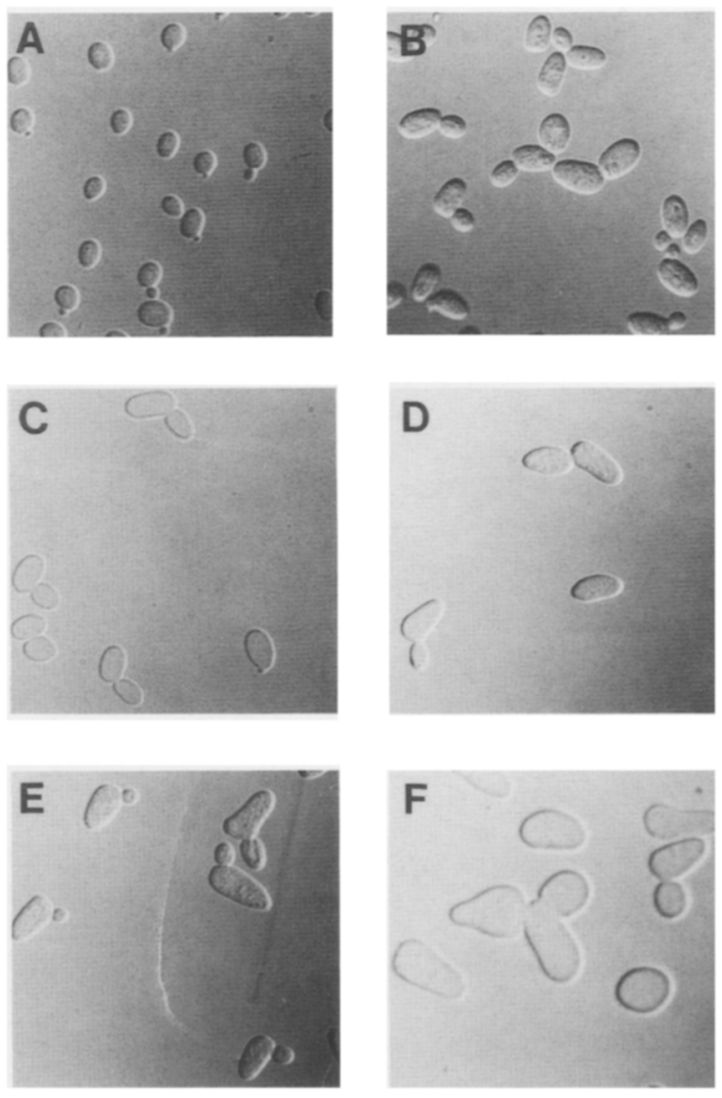

Figure 3. Photomicrographs of $S$. cerevisiae cks1- cells rescued by CKShs1 or CKShs2 expressed from the GAL1 promoter. $(A) C K S 1^{+}$cells carrying YCpG2 in galactose medium; (B) cks1- cells carrying YCpG2[CKS1] in galactose medium; (C) cks1- cells carrying YCpG2[suc1 $\left.{ }^{+}\right]$in galactose medium; $(D)$ cks1- cells carrying YCpG2[CKShs1] in galactose medium; $(E)$ cks1- cells carrying YCpG2[CKShs2] in galactose medium; $(F)$ cks1- cells carrying YCpG2[CKShs1] $72 \mathrm{hr}$ after shifting to glucose medium. 


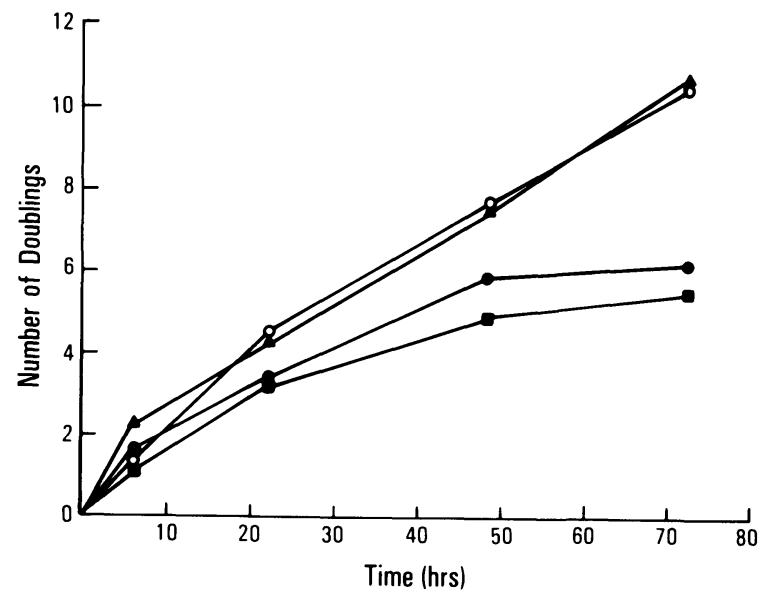

Figure 4. Kinetics of growth arrest of $S$. cerevisiae cks $^{-}$cells after repressing transcription of CKShs1 or CKShs2 from the GAL1 promoter. Cell numbers were determined with time from cultures grown in galactose minimal media without uracil or after the addition of glucose. The data are represented as the number of divisions (the natural log of the increase in cell number) as a function of time. ( $\mathbf{\Delta}) \mathrm{cks}^{-} \mathrm{YCpG}$ [CKShs1] in galactose; (O) $\mathrm{cks}^{-}$YCpG2[CKShs2] in galactose; (O) $\mathrm{cks}^{-}$ YCpG2[CKShs1] in glucose; (口) cks- YCpG2[CKShs2] in glucose.

fact that the human CKS1 homologs do not allow as many divisions as the yeast CKS1 homologs may be due to differential levels of expression or to differential protein stability.

\section{Human CKS1 cDNAs encode smaller proteins than yeast CKS1 genes}

It has been reported by Draetta et al. (1987) that HeLa cells contain a protein that cross-reacts with a polyclonal antibody directed against $S$. pombe Sucl. These investigators report evidence that this potential homolog, present in HeLa cell extracts, migrates on an SDS-polyacrylamide gel at the same molecular mass as the $S$. pombe Sucl protein $(13 \mathrm{kD})$. The CKS1 homologs that we cloned from HeLa cells are expected to encode proteins of only $8.7 \mathrm{kD}$ and thus would be expected to migrate on SDS-polyacrylamide gels at a smaller molecular mass compared with the $S$. pombe Sucl protein. To investigate the relative molecular masses of the Cksl homologs, CKShs1, CKShs2, S. cerevisiae CKS1 and S. pombe suc1 ${ }^{+}$were cloned into the bacterial expression vector pRK171 (Rosenberg et al. 1987; see Experimental procedures). The bacterially produced proteins were precipitated with $80 \%$ ammonium sulfate, purified through a Sephacryl S-200HR sizing column, run on a $20 \%$ SDSpolyacrylamide gel, and stained with Coomassie Blue (Fig. 5). As shown in Figure 5, the Ckshs1 and Ckshs2 proteins migrate at $\sim 9 \mathrm{kD}$ (lanes 1 and 2), the $S$. pombe Sucl protein migrates at $13 \mathrm{kD}$ (lane 4 ), and the $S$. cerevisiae Cksl protein migrates at $18 \mathrm{kD}$ (lane 3). Thus, it is clearly evident that the human Cks proteins migrate with a greater mobility than the yeast Cks proteins, as predicted from their amino acid sequences. The discrepancy between the molecular masses of the proteins en- coded by the human CKS1 homologs determined here and that reported by Draetta et al. (1987) will be addressed in the Discussion.

mRNA abundance of the two human CKS1 homologs varies through the cell cycle in HeLa cells

The presence of two CKS1 homologs in human cells suggested that they may be used differently in the cell cycle. Thus, it was of interest to determine whether the mRNAs corresponding to the two CKShs homologs were expressed differentially through the cell cycle. HeLa cells were fractionated on the basis of cell size by centrifugal elutriation (see Experimental procedures). The first fractions contain the smallest cells in the $G_{1}$ phase of the cell cycle, and the last fractions are enriched for cells in $G_{2}$ and $M$ phases. To confirm that good separation of cells had been obtained, the fractions were analyzed for nuclear DNA content by staining with propidium iodide, followed by flow cytometry (Fig. 6A). RNA was prepared and analyzed on a single Northern blot by first using a probe specific for CKShs1 and stripping and reprobing for CKShs2 mRNA (see Experimental procedures). mRNAs of $\sim 0.7 \mathrm{~kb}$ were detected for both CKShs1 and CKShs2 (Fig. 6B), consistent with the size of the cDNA clones. The intensity of the mRNA signal in each lane was quantitated against an internal standard (human $\beta$-actin mRNA) by laser densitometric analysis (Fig. 6C). As shown in Figure 6C, CKShs1 mRNA abundance varies differently from that of $C K S h s 2$ through the cell cycle. CKShs1 mRNA is low in $\mathrm{G}_{1}$ cells and increases by fourfold in fractions rich in $\mathrm{G}_{2}$ - to $\mathrm{M}$-phase cells, whereas CKShs2 mRNA is barely detectable in fractions rich in $G_{1}$ cells and increases by sevenfold in $\mathrm{G}_{2}$ - to $\mathrm{M}$-phase cells. Similar results were obtained with cells synchronized by using a double thymidine block/ release rather than by elutriation (Rao and Johnson 1970; data not shown). There is some indication from

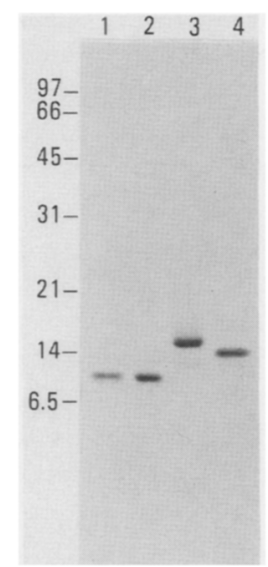

Figure 5. Comparison of the molecular weights of E. coli-produced Cks1 homologs. Purified bacterially produced proteins were run on a $20 \%$ SDS-polyacrylamide gel and stained with Coomassie Blue. (Lane 1) Ckshs1; (lane 2) Ckshs2; (lane 3) Cks1; (lane 4) Sucl. 
A

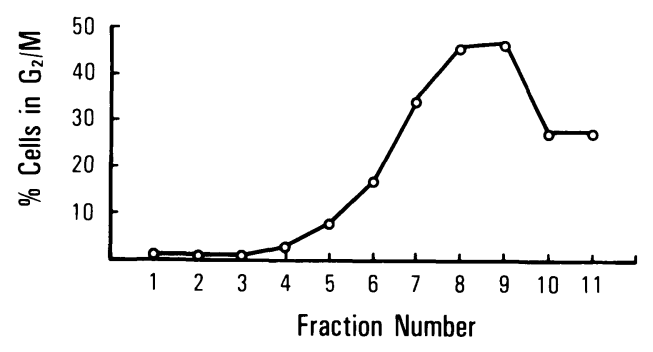

B

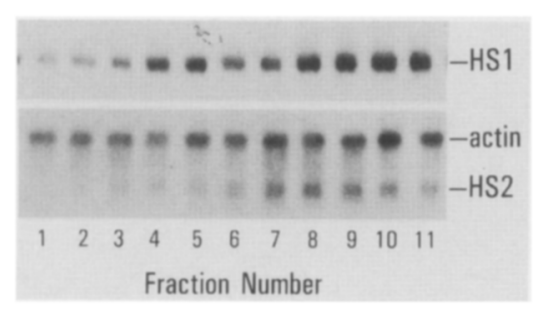

C

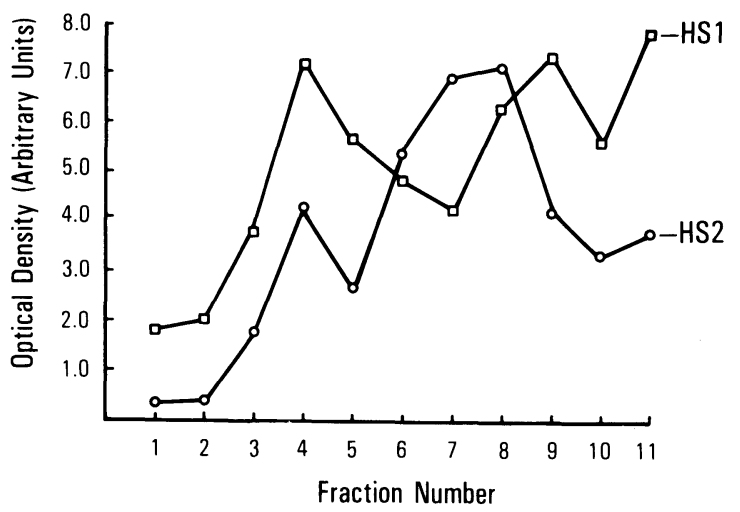

Figure 6. Transcription of CKShs1 and CKShs2 through the cell cycle. HeLa cells in a suspension culture were separated on the basis of size with an elutriator rotor. Aliquots from each sample of cells were either stained with propidium iodide and analyzed for DNA content by flow cytometry, or RNA was prepared for Northern blot analysis. (A) A graphic representation of the fraction of cells in each sample with a $4 n$ DNA content (in $\mathrm{G}_{2}$ or $\mathrm{M}$ phase). (B) Autoradiographs of Northern blots of RNA prepared from the elutriated samples, with radiolabeled probes specific for CKShs1, CKShs2 or $\beta$-actin mRNA. The Northern blot was first hybridized with the CKShs1 probe and stripped and rehybridized with the CKShs 2 and $\beta$-actin probes. $(C) \mathrm{A}$ graphic representation of the relative level of CKShs1 and CKShs2 mRNA normalized to $\beta$-actin mRNA.

these data that expression of $C K S h s 1 \mathrm{mRNA}$ is biphasic, with a small peak at the $G_{1}$ to $S$ boundary and a larger peak near the end of the cell cycle. The peak of S-phase cells in the profile (fractions 6 and 7 in Fig. 6A), based on flow cytometric analysis, separates the two maxima of CKShs1 mRNA. Further experiments are needed to determine whether observed variations in mRNA abundance are due to changes in the synthesis or degradation of mRNA and whether this variation translates into differences in the abundance of the Ckshs proteins through the cell cycle. Such changes in Ckshs protein levels would be predicated on the proteins being unstable, which is apparently not so when they are expressed in yeast. Their stability in human cells remains to be determined. Note that the estimate of mRNA variation is a minimal one due to the impurity of the elutriated fractions rich in S-phase and $\mathrm{G}_{2}$ - to M-phase cells. Only fractions 1-4 were homogeneous, containing exclusively $G_{1}$ cells. In addition, we have used $\beta$-actin mRNA as an internal standard, assuming that it would be constant in level through the cell cycle. However, it is apparent that this mRNA increases slightly in abundance as a function of cell-cycle progression (Fig. 6B). Both the fluctuations in CKShs1 and CKShs2 mRNAs, as well as in actin mRNA, were reproducible in several different experiments.

\section{Ckshs1 and Ckshs2 bind to the Cdc2/Cdc28 protein kinase from $\mathrm{S}$. cerevisiae and HeLa cells}

A property of the $S$. pombe Sucl protein and the $S$. cerevisiae Cks1 protein is that they bind to Cdc2/Cdc28 (Brizuela et al. 1987; Draetta et al. 1987; Draetta and Beach 1988; Dunphy et al. 1988; Hadwiger et al. 1989b). Both Sucl/Cks1 antibodies and Suc1-Sepharose beads have been used to adsorb Cdc2/Cdc28 protein kinase activity. To confirm that the cloned CKShs1 and CKShs2 cDNAs encode proteins that are able to associate with Cdc2/Cdc28, the proteins produced in Escherichia coli were coupled to Sepharose beads (see Experimental procedures). The Ckshs-Sepharose beads were added to cell extracts from exponentially growing HeLa cells. After incubation, the Ckshs-Sepharose beads were washed and assayed for Cdc2hs protein kinase activity using histone $\mathrm{Hl}$ as the substrate. As shown in Figure 7A (lanes 1 and 3), both Ckshs1- and Ckshs2-Sepharose beads bind a protein kinase activity that is active against histone $\mathrm{H} 1$. This protein kinase activity was specifically associated with the Ckshs proteins because the ability to phosphorylate histone $\mathrm{Hl}$ could be blocked by prior addition of free $\mathrm{Ckshs}$ protein to the cell extract (Fig. 7A, lanes $2,4,6,7)$. These results suggest that the human Cks1 homologs specifically associate with the Cdc2 protein kinase in human cells.

The ability of Ckshs1 and Ckshs2 to interact with $\mathrm{Cdc} 2 / \mathrm{Cdc} 28$ was also investigated in $S$. cerevisiae cells where mutations in $C D C 28$ could be used to confirm that the human Cks1 homologs were indeed interacting specifically with the Cdc28 protein kinase. As shown in Figure 7B (lanes 3 and 5) Ckshs-Sepharose beads incubated with a protein extract from exponentially growing $S$. cerevisiae $C D C 28^{+}$cells bind a kinase activity that is active against exogenously added histone $\mathrm{Hl}$ and an endogenous 40-kD protein, p40 (Reed et al. 1985; Mendenhall et al. 1987). Under the same assay conditions, both exogenously added histone $\mathrm{Hl}$ and the endogenous substrate p40 are phosphorylated when Cdc28 antisera or Cks1 antisera are used to precipitate Cdc28 protein kinase from exponentially growing $S$. cerevisiae cell ex- 


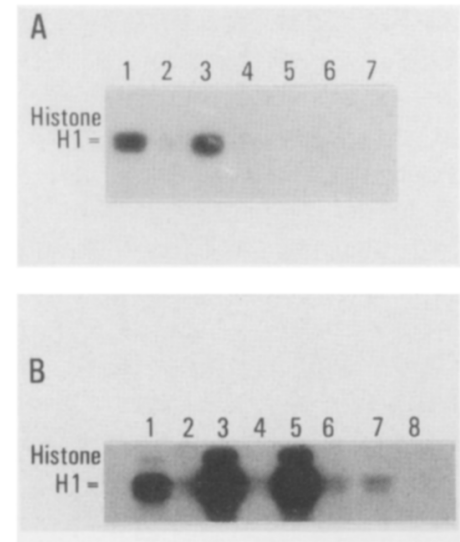

Figure 7. Protein kinase assays with Ckshs-Sepharose beads. (A) Protein kinase assays of HeLa cell protein extracts. (Lane 1) Ckshs1-Sepharose beads; (lane 2) Ckshs1-Sepharose beads with the addition of excess free Ckshsl protein; (lane 3) Ckshs2-Sepharose beads; (lane 4) Ckshs2-Sepharose beads with the addition of excess free Ckshs2 protein; (lane 5) mock beads; (lane 6) Ckshs1-Sepharose beads with the addition of excess free Ckshs2 protein; (lane 7) Ckshs2-Sepharose beads with the addition of excess free Ckshsl protein. $(B)$ Protein kinase assays of $S$. cerevisiae $C D C 28^{+}$or $c d c 28-4$ (cdc28 temperature-sensitive allele) protein extracts. (Lane 1) immunoprecipitation from $\mathrm{CDC} 28^{+}$cell extracts with $\mathrm{Cdc} 28$ amino-terminal antiserum; (lane 2) immunoprecipitation from $c d c 28-4$ cell extracts with Cdc28 amino-terminal antisera; (lane 3) Ckshsl beads with $C D C 28^{+}$cell extracts; (lane 4) Ckshsl beads with $c d c 28-4$ cell extracts; (lane 5) Ckshs2 beads with $C D C 28^{+}$ cell extracts; (lane 6) Ckshs2 beads with $c d c 28-4$ cell extracts; (lane 7) mock beads with $C D C 28^{+}$cell extracts; (lane 8) mock beads with $c d c 28-4$ cell extracts. The band above the histone $\mathrm{H} 1$ band (indicated) is the endogenous substrate p40 (Reed et al. 1985; Mendenhall et al. 1987). Samples were prepared as described in Experimental procedures.

tracts (Fig. 7B, lane 1; Hadwiger et al. 1989a). When the Ckshs-Sepharose beads were incubated with extracts from a strain carrying a temperature-sensitive allele of CDC28, cdc28-4 (from which no Cdc28 activity is detected in the in vitro assay; Reed et al. 1985; Mendenhall et al. 1987), no significant activity was observed against histone $\mathrm{Hl}$ and no $\mathrm{p} 40$ phosphorylation was detectable. This result indicates that the human Cks proteins are indeed able to bind to the Cdc28 protein kinase complex in vitro in an active form.

\section{Discussion}

By using a cloning strategy based on the technique of PCR, we identified two homologs of the $S$. cerevisiae CKS1 gene from human cells. The degenerate primers used for PCR were derived from the amino acid sequences of two CKS1 homologs from the distantly related yeasts $S$. cerevisiae and S. pombe. This strategy has also been used successfully to clone CKS1 homologs from Xenopus and Drosophila (H.E. Richardson, P. Russell, and S.I. Reed, unpubl.). In addition, this approach has been successful for obtaining homologs of the $S$. pombe mitotic inducer $c d c 25^{+}$from human cells /Sadhu et al. 1990).

The human CKS1 homologs, CKShs1 and CKShs2, represent the first members of the Cks1 protein family from higher eukaryotes. Although CKShs1 and CKShs2 cDNAs encode proteins that have $\sim 55 \%$ identity to the yeast CKS1 homologs, they show several distinct differences, the most striking being the deletion of 9 amino acids in the middle of the protein relative to the yeast proteins. Despite this deletion and their considerably smaller size (a molecular mass of $9 \mathrm{kD}$ compared with $18 \mathrm{kD}$ for $S$. cerevisiae Cksl and $13 \mathrm{kD}$ for $S$. pombe Suc1), they are both able to rescue a null mutation in the $S$. cerevisiae CKS1 gene. Cks1 has a region of polyglutamine at the carboxyl terminus that is not present in either the $S$. pombe or human Cksl homologs. The observation that both $S$. pombe suc1 $1^{+}$and human CKShs1 and CKShs2 are able to replace the $S$. cerevisiae CKS1 gene to allow normal mitotic growth of $S$. cerevisiae cells suggests that the polyglutamine region does not perform any essential function.

The fact that the human CKShs1 and CKShs2 cDNAs encode considerably smaller proteins than the yeast CKS1 homologs was surprising in light of the results of Draetta et al. (1987). Using anti-p13 ${ }^{\text {sucl }}$ antisera, Draetta et al. (1987) detected a protein from human cells that comigrated with the $S$. pombe Sucl protein at $\sim 13 \mathrm{kD}$. This discrepancy prompted a comparison of the molecular masses of the four Cks1 homologs by SDS-PAGE (Fig. 5). The proteins encoded by CKShs 1 and CKShs2 cDNAs migrate at $\sim 9 \mathrm{kD}$ on an SDS-polyacrylamide gel (Fig. 5). There are several possible explanations for this apparent discrepancy: (1) Different gel systems may have been used; (2) Ckshs protein may be modified in vivo, thereby modifying its mobility; (3) additional homologs of $13 \mathrm{kD}$ may exist in human cells that were not detected by the PCR approach; and (4) the species detected by Draetta et al. (1987) was not a true Cks1/Sucl homolog. Antibodies against the human Cks1 homologs are presently being prepared to distinguish between the various possibilities.

\section{Role of Cks1 homologs}

In this study we initiated an investigation of the role of the human Cksl homologs in the cell cycle by cloning the cDNAs and demonstrating that they can replace the $S$. cerevisiae CKS1 gene in allowing normal mitotic growth. The rescue of the $S$. cerevisiae CKS1 null mutation by the human CKShs1 and CKShs2 cDNAs indicates that they can replace all functions of the endogenous gene. We have shown that this is also true for the $S$. pombe suc1 $1^{+}$gene. In $S$. cerevisiae, the CKS1 function has been demonstrated to be required for the $G_{1}$ - to $S$ phase transition (Hadwiger et al. 1989a; S.I. Reed, unpubl.). A role for the $S$. cerevisiae Cksl protein in the $\mathrm{G}_{2}$ to $M$ phase has not been demonstrated, yet it is known that Cks1 associates with Cdc28 protein kinase at this stage of the cell cycle (C. Wittenberg and S.I. Reed, un- 
publ.). Cdc28 has recently been demonstrated to have a $\mathrm{G}_{2}$ role (Reed and Wittenberg 1990); however, this role was not apparent from the terminal phenotype of $c d c 28$ temperature-sensitive alleles (Hartwell et al. 1974; Reed 1980) and could only be demonstrated by inhibitor shift experiments where Cdc28 kinase activity was allowed to decay in cells arrested in $S$ or $G_{2}$ phase (Wittenberg et al. 1990). The data suggest that in $S$. cerevisiae, the requirement for $\mathrm{Cdc} 28$ is greater in the $G_{1^{-}}$to $S$ phase transition than in the $G_{2}-$ to $M$-phase transition. Thus, when Cdc28 activity is made limiting, there is a tendency for cells to arrest at $G_{1}$. It is possible that the $\mathrm{G}_{1}$ arrest conferred by cks1 mutations is a manifestation of this apparent differential requirement of $\mathrm{Cdc} 28$ activity in $G_{1}$ relative to $G_{2}$. Further analysis will be required to confirm this. The biphasic pattern of expression of CKShs1 mRNA relative to the human cell cycle is consistent with the possibility of both $a G_{1}$ and $G_{2} / M$ function in higher cells.

In S. pombe cells, the role of the suc1 ${ }^{+}$gene in the cell cycle has been investigated by analysis of germinating suc1- ${ }^{-}$spores (Moreno et al. 1989). It was found that suc1- cells arrested with long mitotic spindles, no cytoplasmic microtubules, and condensed chromosomes, consistent with an anaphase or telophase arrest. It was also observed that Cdc2 protein kinase activity was threefold higher in suc1- cells compared with suc1 ${ }^{+}$ germinating spores. These results were interpreted as evidence that Sucl is required in anaphase/telophase for the reduction in activity of the Cdc2 protein kinase, which is necessary for cells to exit from mitosis (Murray et al. 1989). However, these results may also be interpreted to indicate that Sucl is required for the function of Cdc2 protein kinase in mitosis, as explained below. Because only $5 \%$ of the Sucl protein present in the cell is complexed with Cdc2 (Brizuela et al. 1987), there may be enough of the protein present in germinating spores (even though it was undetectable by immunoblot analysis; Moreno et al. 1989) to allow the Cdc2 protein kinase to function in the $G_{1}$ - to S-phase transition and to initiate mitosis, but the level of Sucl may have decreased below a threshold level required for the completion of some early mitotic events. The higher level of Cdc2 protein kinase activity observed in the suc1- germinating spores may be explained by the fact that these cells are arresting in mitosis and thus are synchronized at a point where kinase activity is high, whereas the suc $1^{+}$cells continue cycling. The fact that $\mathrm{Cdc} 2$ protein kinase activity remains high in suc1- germinating spores suggests that the loss of Sucl is not required for the maintenance of $\mathrm{Cdc} 2$ protein kinase activity but may be involved in targeting the Cdc2 protein kinase to substrates or some other critical function. Thus, in suc1- cells the appropriate substrates may not be phosphorylated in mitosis, resulting in mitotic arrest even with an excess of active kinase.

Several studies involving the $S$. pombe Sucl protein have suggested that the Cks1 homologs are inhibitors of mitotic induction. The overexpression of Sucl in $S$. pombe results in a delay in entry into mitosis (Hayles et al. 1986b; Hindley et al. 1987). In the work described in this paper, S. cerevisiae CKS1, S. pombe suc1+ and human CKShs 1 and CKShs2 cDNAs were overexpressed in the $S$. cerevisiae cks1- null mutant. All four strains gave rise to slightly larger and more elongated cells than a $\mathrm{CKS1}^{+}$strain (Fig. 3), and preliminary analysis suggests that this is attributable to a delay at the $G_{2}$ - to $M$ phase transition. Similarly, experiments in the Xenopus system have led to the proposal that Cksl homologs act as an inhibitor of Cdc2 activation at the $\mathrm{G}_{2}$ - to $\mathrm{M}$-phase transition by preventing dephosphorylation at tyrosine residues on the Cdc2 protein (Dunphy et al. 1988; Dunphy and Newport 1989). However, in that study the heterologous $S$. pombe Sucl protein was added to extracts from Xenopus embryos, and the results obtained may be due to inappropriate interactions occurring between heterologous proteins. Likewise, the same argument can be used to explain the inhibitory effect on cell division observed when $S$. pombe Sucl is injected into rat fibroblasts in the experiments of Riabowol et al. (1989). Alternatively, it is possible that the concentrations of Sucl used in these experiments were much higher than the normal cellular levels of the endogenous proteins; therefore, their results may represent a nonphysiological consequence of a stoichiometric imbalance in interacting proteins. This explanation is consistent with the inhibition of cell-cycle progression observed when the Cksl homologs are overexpressed in yeast (Hayles et al. 1986b; Hindley et al. 1987; H.E. Richardson and S.I. Reed, unpubl.).

Studies on the Cdc2 protein kinase (after purification of MPF activity or histone Hl kinase activityl from Xenopus oocytes, marine invertebrate oocytes, and human cells have not addressed whether Cksl homologs are normally components of the active kinase complex (Arion et al. 1988; Gautier et al. 1988, 1990; Labbe et al. 1988, 1989a,b; Lohka et al. 1988; Brizuela et al. 1989; Draetta et al. 1989; Langan et al. 1989; Meijer et al. 1989; Pondaven et al. 1990). In the analysis of the components of purified MPF or histone H1 activity, these workers used gel systems that would not have resolved the small Cks1 homologs. Furthermore, in some cases, p13 ${ }^{\text {Sucl }}$-Sepharose beads were used to purify the activity, and Sucl may therefore have displaced the endogenous protein. In this work we have demonstrated that Ckshs-Sepharose beads can bind the active form of the Cdc2 protein kinase, as assayed by the ability to phosphorylate histone $\mathrm{H} 1$. The preparation of antisera against Ckshs1 and Ckshs2 proteins will enable us to investigate whether these proteins are normally components of MPF and histone H1 kinase in human cells and whether their relative abundance varies through the cell cycle, as is suggested by their transcription patterns.

In conclusion, we have demonstrated that human cells contain proteins that are structurally and functionally conserved with the small subunit $\left(\mathrm{Cks} / \mathrm{Sucl}^{+}\right)$of the $\mathrm{Cdc} 28 / \mathrm{Cdc}^{+}$protein kinase from yeast. This presents another example of the strong conservation of cell-cycle control mechanisms and components in eukaryotic organisms. 


\section{Experimental procedures}

Yeast strains, genetic procedures, media, and growth conditions

All yeast strains used in this study were derivatives of

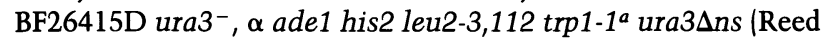
et al. 1985; Richardson et al. 1989). The $c d c 28$ temperaturesensitive strain, (cdc284), used to prepare protein extracts, was D4, $\alpha$ ade1 his2 leu2-3, 112 trp1-1 $1^{\text {a }}$ cdc28-4 (Reed et al. 1985).

Standard genetic procedures for yeast were used (Sherman et al. 1982). Yeast transformations were carried out by the alkali cation method (Ito et al. 1983). Genomic sequence replacements were performed as described by Rothstein (1983).

The strain used to test for rescue of the $S$. cerevisiae cks1 null allele, cks1:: LEU2 (CEN1 TRP1 CKS1), was constructed as follows. The cks1 :: LEU2 allele was prepared in vitro by insertion of the LEU2 gene as a HindIII-SmaI fragment (from a pUC19 clone in the SalI site) into the unique HindIII site present in CKS1, which was cloned as a $0.72-\mathrm{kb}$ XhoI-EcoRI fragment into a pBluescript plasmid (see Hadwiger et al. 1989a). The endogenous CKS1 gene was replaced by the cks1:: LEU2 allele by transformation of BF264-15D ura3- diploid yeast cells with pBluescript[cks1 :: LEU2] DNA digested with XhoI and StuI (see Hadwiger et al. 1989a) and selection for Leu ${ }^{+}$colonies. This strain, heterozygous for cks1:: LEU2, was transformed with the CEN1 :: TRP1 :: CKS1 plasmid, (pSE271[CKS1]), and $\mathrm{Trp}^{+}$colonies were selected. The haploid strain carrying the cks1 :: LEU2 null allele and the pSE271[CKS1] plasmid were obtained by sporulation and dissection of the diploid and screening for $\mathrm{Leu}^{+}$and $\mathrm{Trp}^{+}$segregants.

Yeast cultures were grown in YEP ( $1 \%$ yeast extract, $2 \%$ bactopeptone, $0.005 \%$ adenine, $0.005 \%$ uracil) supplemented with glucose $(2 \%)$ or galactose $(2 \%)$ as the carbon source, except when selection for plasmids was required; cells were then grown in minimal media supplemented with amino acids and adenine but lacking uracil.

HeLa cells were grown in suspension culture in Joklik's modified Eagle medium containing $10 \%$ (vol/vol) equine serum and 10 mM HEPES (pH 7.4).

\section{Cloning the CKShs CDNA}

The degenerate oligonucleotides used in the PCR technique for cloning human homologs of $C K S 1$ had the following sequences: $5^{\prime}$ primer, 5'-AGAGCTCGAGAYGAYRANTAYGARTAYMGNCAYGTNATG-3' corresponding to the amino acid sequence DD(NE)YEYRHVM; 3' primer, 5'-ATCTCGAGATCGATTRAANARNARNATRTGNGGYTCNGG-3', corresponding to the amino acid sequence PEPHILLFK $(\mathrm{Y}=\mathrm{C}+\mathrm{T}$, $\mathbf{R}=\mathbf{A}+\mathbf{G}, \mathbf{M}=\mathbf{A}+\mathbf{C}, \mathbf{N}=\mathbf{A}+\mathrm{G}+\mathrm{C}+\mathrm{T})$. The XhoI and ClaI restriction sites are underlined. The PCR incubations were for 40 cycles of $94^{\circ} \mathrm{C}$ for $1 \mathrm{~min}, 45^{\circ} \mathrm{C}$ for $2 \mathrm{~min}$ and $72^{\circ} \mathrm{C}$ for $3 \mathrm{~min}$ in a DNA Thermal Cycler (Perkin-Elmer Cetus). The reactions consisted of $50 \mathrm{mM} \mathrm{KCl}, 10 \mathrm{mM}$ Tris- $\mathrm{HCl}(\mathrm{pH} 8.3$ ), 1.5 $\mathrm{mM} \mathrm{MgCl}, 0.01 \%$ gelatin, $0.2 \mathrm{~mm}$ each of dATP, dCTP, dGTP, and dTTP, 0.025 units of Taq DNA polymerase (Perkin-Elmer Cetus), $10 \mu \mathrm{g}$ of each oligonucleotide set, and $5 \mu \mathrm{g}$ of DNA prepared from a HeLa cell cDNA library (kindly provided by Steve Gould, University of California, San Diego). The HeLa cell cDNA library was made in the plasmid pCD (Okayama and Berg 1983) by Steve Hanks (Salk Institute, La Jolla, California). The PCR products were digested with $\mathrm{XhoI}$ and ClaI restriction enzymes, gel-purified, and cloned into the $\mathrm{XhoI}$ and $\mathrm{ClaI}$ sites of pBluescript SK (Stratagene).

To obtain cDNA clones, the two CKShs PCR clones were used to make radiolabeled probes to screen a HeLa cell cDNA library. Initially, the HeLa cell cDNA library made by Steve Hanks was used; however, only one clone (CKShs2) was obtained after screening 50,000 colonies. The DNA sequence of this clone was determined in both directions after constructing subclones from the internal SacI, BglII, and PstI sites (Fig. 1B) in pT7T319U (Pharmacia). A HeLa cell (D98/AH-2) cDNA library in the vector Lambda Zap II (Stratagene) was then screened with radiolabeled probes made from the CKShs1 PCR clone and the CKShs2 cDNA clone. Many positive clones were obtained $(\sim 100$ of 200,000 plaques). Several of these were purified, and pBluescript SK phagemids were derived from the $\lambda$ phage by in vivo excision following the manufacturer's protocol (Stratagene). Restriction analysis revealed that they represented both CKShs 2 and CKShs1 cDNA clones. The largest CKShs1 cDNA clone was sequenced completely from the pBluescript SK clone and from subclones obtained from the internal HindIII site (Fig. 1A) in pT7T319U (Pharmacia). Sequence analysis of the CKShs cDNA revealed that it lacked a poly(A) tail, which may have occurred during the in vivo excision process used to obtain the clone in a plasmid form.

\section{Recombinant DNA manipulations}

The CEN1 :: TRP1 :: CKS1 plasmid, pSE271[CKS1], was constructed by insertion of a BamHI-XhoI fragment containing the $C K S 1$ gene, which was derived from an EcoRI clone of CKS1 in the phagemid pT7T319U (Hadwiger et al. 1989a), into the unique BamHI and SalI sites of pSE271. The plasmid pSE271 was obtained from R.W. Davis.

Clones of CKShs1, CKShs2, CKS1, and suc1 ${ }^{+}$were obtained in the yeast GAL1 expression vector, YCpG2 (Richardson et al. 1989), by constructing BamHI restriction sites in vitro at the 5' and $3^{\prime}$ ends of the protein-coding regions and cloning the BamHI fragments into YCpG2 at the unique BamHI site (located 3' of the GAL1 promoter). The following pairs of primers were used to create $B a m H I$ restriction sites at the $5^{\prime}$ and $3^{\prime}$ ends of the protein-coding regions of CKS1 homologs by PCR: CKShs1 5' end, 5'-GGGATCCGATCATGTCGCACAAAC-3', corresponding to bases 5-22 (Fig. 1A); CKShs1 $3^{\prime}$ end, 5'GGGATCCAGTTACCAGCACATTC-3' corresponding to the reverse complement of bases 381-397 (Fig. 1A); CKShs2 5' end, 5'-GGGATCCGGATGGCCCACAAGCAG-3', corresponding to bases 94-110 (Fig. 1B); CKShs2 3' end, 5'-GGGATCCGATTTGACGATCCCCAG-3', corresponding to the reverse complement of bases 343-359 (Fig. 1B); CKS1 $5^{\prime}$ end, 5' CCGGATCCAGTACTATGTACCATCA-3'; CKS1 3' end, 5'. CCGGATCCGAATTCAATTTCAGTAAT-3' (see Hadwiger et al. 1989a); suc1 ${ }^{+} 5^{\prime}$ end, CCGGATCCAATATGTCGAAAAGTGGTG; suc1 ${ }^{+} 3^{\prime}$ end, 5'-CCGGATCCGTTGGAGTTGACAAACT-3' (see Hindley et al. 1987). BamHI restriction sites are underlined.

For the production of Cks proteins in bacteria, clones of the CKS1 homologs were obtained in the bacterial expression vector pRK171 (Rosenberg et al. 1987), as described below. A NdeI restriction site was constructed at the $5^{\prime}$ end, and a BamHI restriction site was constructed at the $3^{\prime}$ end of the protein-coding regions of the CKS1 homologs by PCR, with the CKShs $3^{\prime}$-end BamHI primers described above and the following 5 '-end NdeI primers: CKShs 15 '-end, 5' -CCCATGTCGCACAAACAAATT-3', corresponding to bases 10-27 (Fig. 1A); CKShs2 5'-end, 5'-CCCATATGGCCCACAAGCAGATC-3', corresponding to bases 96-113 (Fig. 1B); CKS1 5'-end, 5'GCCATATGTACCATCACTATCAC-3' (see Hadwiger et al. 1989a); suc1 ${ }^{+}$5'-end, 5'-GCCATATGTCGAAAAGTGGTG-3' (see Hindley et al. 1987). NdeI restriction sites are underlined. The NdeI-BamHI fragments were cloned into the NdeI and 
BamHI sites of pRK171, resulting in the fusion of the proteincoding frames of CKShs1 and CKShs2 with a strong bacterial translation initiation signal (Rosenberg et al. 1987).

The PCR conditions used for the in vitro construction of restriction sites were as described above except that the hybridization temperature was adjusted to be $5^{\circ} \mathrm{C}$ below the average melting temperature of the two primers. The template DNA (from plasmid clones of the appropriate CKS1 homologs) was added to the reactions at a final concentration of $10 \mathrm{pg} / \mu \mathrm{l}$.

\section{Photomicroscopy and cell counting}

Yeast cells were fixed in $70 \%$ ethanol, and cell number was determined with a hemacytometer and a Nikon Optiphot microscope with phase-contrast optics at $400 \times$ magnification. Cells were photographed by use of differential interference contrast (Nomarski) optics with a $100 \times$ objective.

\section{Cell synchrony and Northern analysis}

For the fractionation of HeLa cells by centrifugal elutriation, a 3 -litre suspension culture of HeLa cells was grown to a density of $5 \times 10^{5}$ cells $/ \mathrm{ml}$. Cells were loaded onto a Beckman JE5.0 elutriator rotor spinning at $2500 \mathrm{rpm}$ at a rate of $125 \mathrm{ml} / \mathrm{min}$, and the flow rate was adjusted to $75 \mathrm{ml} / \mathrm{min}$ and the centrifugal speed was adjusted to $1550 \mathrm{rpm}$. Aliquots $(400 \mathrm{ml})$ were taken as the flow rate was increased at $10 \%$ increments. Samples were analyzed for DNA content after staining cells with propidium iodide, as described by Draetta and Beach (1988), with a Becton Dickinson FACS IV analyzer. RNA was prepared from the samples by use of guanidinium isothyocyanate (Chirgwin et al. 1979). RNA samples (10 $\mu \mathrm{g}$ of each) were electrophoresed on a $1 \%$ agarose-formaldehyde gel. RNA size markers $(0.24$ - to 9.5-kb RNA ladder, BRL) were run on the gel and stained with ethidium bromide. RNA was electroblotted to a Biotrans (ICN) nylon membrane.

Radiolabeled probes were made by use of the random primer DNA labeling kit (Boehringer-Mannheim) according to the manufacturers' instructions. The CKShs1 probe was prepared from the NdeI-BamHI clone of CKShs1 in pRK171, and the CKShs2 probe was prepared from a $0.6-\mathrm{kb}$ BamHI-SacI fragment containing the complete coding region obtained from the cDNA clone. The $\beta$-actin probe was prepared from a $2.3-\mathrm{kb}$ BamHI fragment encoding the cDNA (Ponte et al. 1984). Hybridizations and washes were performed as described by Reed et al. (1982). An Ultrascan XL laser densitometer (LKB) was used to scan the autoradiographs to quantitate the relative levels of the CKShs transcripts in each sample relative to $\beta$-actin mRNA.

Expression of proteins in bacteria and preparation of CkshsSepharose beads

Cks proteins were overproduced in bacteria by use of the $\mathrm{T} 7$ expression system, described by Rosenberg et al. (1987). Two grams of induced cells (B-lysS strain) carrying pRK171[CKShs1], pRK171[CKShs2], pRK171[CKS1], or pRK171[suc1+] plasmids, was lysed in $50 \mathrm{~mm}$ Tris- $\mathrm{HCl}(\mathrm{pH} 8), 2 \mathrm{~mm}$ EDTA, and $10 \%$ glycerol, followed by sonication for $2 \mathrm{~min}$. Polyethylene amine (pH 7.5) was added to $0.25 \%$ (vol/vol), and the lysate was centrifuged at $11,000 \mathrm{~g}$ for $15 \mathrm{~min}$. The supernatant was removed, ammonium sulfate was added to $80 \%(\mathrm{wt} / \mathrm{vol})$, and proteins were precipitated at $9000 \mathrm{~g}$ for $20 \mathrm{~min}$. The protein pellet was resuspended in $50 \mathrm{mM}$ Tris- $\mathrm{HCl}(\mathrm{pH} 8), 100 \mathrm{mM} \mathrm{NaCl}$, and 2 mM EDTA and run through a $1.6 \times 65-\mathrm{cm}$ Sephacryl S-200HR column at a flow rate of $11 \mathrm{ml} / \mathrm{hr}$. Fractions containing the protein, identified by SDS-PAGE on a $15 \%$ gel, were pooled.

Ckshs protein, prepared as described above, was coupled to cyanogen bromide-Sepharose as described by the manufacturer (Pharmacia). The coupling density obtained for the CkshsSepharose beads was $0.14 \mathrm{mg} / \mathrm{ml}$ for both Ckshs1 and Ckshs2 protein.

\section{Protein kinase assays and SDS-PAGE}

Yeast cell protein extracts were prepared from exponentially growing $C D C 28^{+}$or $c d c 28$ temperature-sensitive mutant (cdc28-4) cells, as described by Wittenberg and Reed (1988). The HeLa cell protein extract was kindly supplied by Clare McGowan (Scripps Clinic, La Jolla, California), as a 140,000 $\mathrm{g}$ supernatant at a concentration of $30 \mathrm{mg} / \mathrm{ml}$.

For Cdc $2 / \mathrm{Cdc} 28$ protein kinase assays with Ckshs-Sepharose beads, $30 \mu \mathrm{l}$ of Ckshs-Sepharose beads was incubated with $15 \mu \mathrm{g}$ of HeLa cell protein or $40 \mu \mathrm{l}$ of yeast cell extract in lysis buffer [ $1 \%$ sodium deoxycholate, $1 \%$ Triton, $0.1 \%$ SDS, $50 \mathrm{~mm}$ Tris- $\mathrm{HCl}$ (pH 7.2), $1 \mathrm{~mm}$ sodium pyrophosphate] on ice for $1 \mathrm{hr}$. For competition experiments, Ckshs1 or Ckshs2 protein was added to the incubations at a final concentration of $0.05 \mathrm{mg} / \mathrm{ml}$. After incubation, the Ckshs-Sepharose beads were washed three times in RIPA buffer (lysis buffer containing $300 \mathrm{~mm}$ $\mathrm{NaCl}$ ), once in lysis buffer without SDS or sodium pyrophosphate, and finally, two times with reaction buffer $[20 \mathrm{~mm}$ Tris$\mathrm{HCl}$ (pH 7.5), $4 \mathrm{~mm} \mathrm{MgCl}_{2}, 0.8 \mathrm{mM}$ EGTA]. Protein kinase assays were performed in reaction buffer with the addition of 80 $\mu \mathrm{M}\left[\gamma^{-32} \mathrm{P}\right] \mathrm{ATP}$ and $1 \mu \mathrm{g}$ of histone $\mathrm{H} 1$ (Boehringer-Mannheim Biochemicals) for $30 \mathrm{~min}$ at $37^{\circ} \mathrm{C}$. Reactions were stopped by the addition of an equal volume of $2 \times$ SDS-PAGE sample buffer, and the labeled products were analyzed by electrophoresis on a $10 \%$ SDS-PAGE gel. Gels were dried and exposed to XAR-5 film (Kodak) at $-70^{\circ} \mathrm{C}$ with a Cronex Lightning Plus intensifying screen.

Cdc28 antiserum precipitations of $\mathrm{Cdc} 28$ protein kinase activity were performed with antiserum directed against the amino terminus of Cdc28, as described by Wittenberg and Reed (1988).

\section{Acknowledgments}

We thank Pat O'Farrell for supplying laboratory space, equipment, and materials to H.E.R. for part of this work. We also thank Curt Wittenberg, Jeff Hadwiger, Miguel de Barros Lopes, Gary Cole, Dave Stone, Bill Kalionis, Christian Lehner, Bruce Edgar, and Pat O'Farrell for advice and helpful discussions. We are grateful to Clare McGowan and Larry Gerace for supplying the HeLa cells and the HeLa cell extracts, to Steve Gould for providing HeLa cell cDNA library DNA, and to Steve Hanks for providing a HeLa cell cDNA library. We also appreciate the assistance of Curt Wittenberg with construction of pRK171 clones of suc1 ${ }^{+}$and CKS1, Christian Lehner with photomicroscopy, and Don McQuitty with flow cytometry. This research was supported by National Institutes of Health grants GM-41281 to P.R. and GM-38328 to S.I.R.

The publication costs of this article were defrayed in part by payment of page charges. This article must therefore be hereby marked "advertisement" in accordance with 18 USC section 1734 solely to indicate this fact.

\section{References}

Arion, D., L. Meijer, L. Brizuela, and D. Beach. 1988. cdc2 is a component of the M phase-specific histone H1 kinase: Evidence for identity with MPF. Cell 55: 371-378.

Bailly, E., M. Doree, P. Nurse, and M. Bornens. 1989. p34cdc2 is located in both nucleus and cytoplasm; part is centroso- 
mally associated at $\mathrm{G} 2 / \mathrm{M}$ and enters vesicles at anaphase. EMBO J. 8: 3985-3995.

Beach, D., B. Durkacz, and P. Nurse. 1982. Functionally homologous cell cycle control genes in budding and fission yeast. Nature 300: 706-709.

Booher, R. and D. Beach. 1987. Interaction between $c d c 13^{+}$and $c d c 2^{+}$in the control of mitosis in fission yeast; dissociation of the $\mathrm{G} 1$ and $\mathrm{G} 2$ roles of the $c d c 2^{+}$protein kinase. EMBO I. 6: $3441-3447$.

- 1988. Involvement of $c d c 13^{+}$in mitotic control in Schizosaccharomyces pombe: Possible interaction of the gene product with microtubules. EMBO I. 7: 2321-2327.

Booher, R.N., C.E. Alfa, J.S. Hyams, and D.H. Beach. 1989. The fission yeast $\mathrm{cdc} 2 / \mathrm{cdcl} / 3 / \mathrm{sucl}$ protein kinase regulation of catalytic activity and nuclear localization. Cell 58: 485497.

Bradbury, E.M., R.J. Ingles, and H.R. Matthews. 1974. Control of cell division by very lysine-rich histone $(\mathrm{H} 1)$ phosphorylation. Nature 247: 257-261.

Brizuela, L., G. Draetta, and D. Beach. 1987. pl3 $3^{\text {sucl }}$ acts in the fission yeast cell division cycle as a component of the p34 cdc2 protein kinase. EMBO J. 6: 3507-3514.

1989. Activation of human CDC2 protein as a histone $\mathrm{Hl}$ kinase is associated with complex formation with the p62 subunit. Proc. Natl. Acad. Sci. 86: 4362-4366.

Chambers, T.C., T.A. Langan, E.M. Matthews, and E.M. Bradbury. 1983. H1 histone kinases from nuclei of Physarum polycephalum. Biochemistry 22: 30-37.

Chirgwin, J.J., A.E. Przbyla, R.J. MacDonald, and W.J. Rutter. 1979. Isolation of biologically active ribonucleic acids from sources enriched in ribonuclease. Biochemistry 18: 52945299.

Cisek, L.J. and J.L. Corden. 1989. Phosphorylation of RNA polymerase by the murine homologue of the cell-cycle control protein cdc2. Nature 338: 679-684.

Cross, F. 1988. DAF1, a mutant gene affecting size control, pheromone arrest, and cell cycle kinetics of Saccharomyces cerevisiae. Mol. Cell. Biol. 8: 4675-4684.

Cross, F., J. Roberts, and H. Weintraub. 1989. Simple and complex cell cycles. Annu. Rev. Cell Biol. 5: 341-395.

Draetta, G. and D. Beach 1988. Activation of cdc2 protein kinase during mitosis in human cells: Cell cycle-dependent phosphorylation and subunit rearrangement. Cell 54: 1726.

Draetta, G., L. Brizuela, J. Potashkin, and D. Beach. 1987. Identification of p34 and p13, human homologs of the cell cycle regulators of fission yeast encoded by $c d c 2^{+}$and suc1 ${ }^{+}$. Cell 50: 319-325.

Draetta, G., F. Luca, J. Westendorf, J. Ruderman, and D. Beach. 1989. cdc2 ${ }^{+}$protein kinase is complexed with cyclin A and B: Evidence for proteolytic inactivation of MPF. Cell 56: $829-838$.

Dunphy, W.G. and J.W. Newport. 1989. Fission yeast p13 blocks mitotic activation and tyrosine dephosphorylation of the Xenopus cdc2 protein kinase. Cell 58: 181-191.

Dunphy, W.G., L. Brizuela, D. Beach, and J. Newport. 1988. The Xenopus cdc2 protein is a component of MPF, a cytoplasmic regulator of mitosis. Cell 54: 423-431.

Evans, T., E.T. Rosenthal, J., Youngblom, D. Distel, and T. Hunt. 1983. Cyclin: A protein specified by maternal mRNA in sea urchin eggs that is destroyed at each cleavage division. Cell 33: 389-396.

Gautier, J., C. Norbury, M. Lohka, P. Nurse, and J. Maller. 1988. Purified maturation-promoting factor contains the product of a Xenopus homolog of the fission yeast cell cycle control gene $c d c 2^{+}$. Cell 54: 433-439.
Gautier, J., J. Minshull, M. Lohka, M. Glotzer, T. Hunt, and J. Maller. 1990. Cyclin is a component of maturation-promoting factor from Xenopus. Cell 60: 487-494.

Goebl, M. and B. Byers. 1988. Cyclin in fission yeast. Cell 54: 739-740.

Hadwiger, J.A., C. Wittenberg, M.D. Mendenhall, and S.I. Reed. 1989a. The Saccharomyces cerevisiae CKS1 gene, a homolog of the Schizosaccharomyces pombe suc1+ gene, encodes a subunit of the Cdc28 protein kinase complex. Mol. Cell. Biol. 9: 2034-2041.

Hadwiger, J.A., C. Wittenberg, H.E. Richardson, M. de Barros Lopes, and S.I. Reed. 1989b. A novel family of cyclin homologs that control G1 in yeast. Proc. Natl. Acad. Sci. 86: 6255-6259.

Hagan, I.M., J. Hayles, and P. Nurse. 1988. Cloning and sequencing of the cyclin related $c d c 13^{+}$gene and a cytological study of its role in fission yeast mitosis. J. Cell Sci. 91: 587595.

Hartwell, L.H., J. Culotti, J.R. Pringle, and B.J. Reid. 1974. Genetic control of the cell division cycle in yeast. Science 183: $46-51$.

Hayles, J., D. Beach, B. Durkacz, and P. Nurse. 1986a. The fission yeast cell cycle control gene $c d c 2$ : Isolation of a sequence that suppresses $c d c 2$ mutant function. Mol. Gen. Genet. 202: 291-293.

Hayles, J., S. Aves, and P. Nurse. 1986b. suc1 is an essential gene involved in both the cell cycle and growth in fission yeast. EMBO I. 5: 3373-3379.

Hindley, J. and G.A. Phear. 1984. Sequence of the cell division gene CDC2 from Schizosaccharomyces pombe; patterns of splicing and homology to protein kinases. Gene 31: 129134.

Hindley, J., G. Phear, M. Stein, and D. Beach. 1987. Suc1 ${ }^{+}$encodes a predicted 13-kilodalton protein that is essential for cell viability and is directly involved in the division cycle of Schizosaccharomyces pombe. Mol. Cell. Biol. 7: 504-511.

Hunt, T. 1989. Maturation promoting factor, cyclin and the control of Mphase. Curr. Opin. Cell Biol. 1: 268-274.

Ito, H., Y. Fukuda, K. Murata, and A. Kimura. 1983. Transformation of intact yeast cells treated with alkali cations. $J$. Bacteriol. 153: 163-168.

John, P.C.L., F.J. Sek, and M.G. Lee. 1989. A homolog of the cell cycle control protein p34 ${ }^{\text {cdc2 }}$ participates in the division cycle of Chlamydomonas, and a similar protein is detectable in higher plants and remote taxa. Plant Cell 1: 11851193.

Johnston, M. and R.W. Davis. 1984. Sequences that regulate the divergent GAL1-GAL10 promoter in Saccharomyces cerevisiae. Mol. Cell. Biol. 8: 1440-1448.

Krek, W. and W.A. Nigg. 1989. Structure and developmental expression of the chicken $C D C 2$ kinase. $E M B O I .8: 3071-$ 3078.

Kozak, M. 1981. Possible role of flanking nucleotides in recognition of the AUG initiator codon by eukaryotic ribosomes. Nucleic Acids Res. 9: 5233-5252.

Labbe, J.-C., M.G. Lee, P. Nurse, A. Picard, and M. Doree. 1988. Activation at $\mathrm{M}$-phase of a protein kinase encoded by a starfish homologue of the cell cycle control gene $c d c 2^{+}$. Nature 335: 251-254.

Labbe, J.-C., A. Picard, G. Peaucellier, J.-C. Cavadore, P. Nurse, and M. Doree. 1989a. Purification of MPF from starfish: Identification as the $\mathrm{H} 1$ histone kinase $\mathrm{p} 34^{\mathrm{cdc} 2}$ and a possible mechanism for its periodic activation. Cell 57: 253-263.

Labbe, J.-C., J.-P. Capony, D. Caput, J.-P. Cavadore, J. Derancourt, M. Kaghad, J.-M. Lelias, A. Picard, and M. Doree. 1989b. MPF from starfish oocytes at first meiotic metaphase 
is a heterodimer containing one molecule of cdc2 and one molecule of cyclin B. EMBO J. 8: 3053-3058.

Langan, T.A., J. Gautier, M. Lohka, R. Hollingsworth, S. Moreno, P. Nurse, J. Maller, and R.A. Sclafani. 1989. Mammalian growth-associated $\mathrm{H} 1$ histone kinase: A homolog of $c d c 2+/ \mathrm{CDC} 28$ protein kinases controlling mitotic entry in yeast and frog cells. Mol. Cell. Biol. 9: 3860-3868.

Lee, C.C., X. Wu, R.A. Gibbs, R.G. Cook, D.M. Muzny, and C.T. Caskey. 1988. Generation of cDNA probes directed by amino acid sequence: Cloning of urate oxidase. Science 239: 1288-1291.

Lee, M.G. and P. Nurse. 1987. Complementation used to clone a human homologue of the fission yeast cell-cycle control gene cdc2. Nature 327: 31-35.

Lee, M.G., C.J. Norbury, N.K. Spurr, and P. Nurse. 1988. Regulated expression and phosphorylation of a possible mammalian cell-cycle control protein. Nature 333: 676-679.

Lehner, C.F. and P. O'Farrell. 1989. Expression and function of Drosophila cyclin A during embryonic cell cycle progression. Cell 56: 947-968.

Lohka, M.J., M.K. Hayes, and J.L. Maller. 1988. Purification of maturation-promoting factor, an intracellular regulator of early mitotic events. Proc. Natl. Acad. Sci. 85: 3009-3013.

Lorincz, A.T. and S.I. Reed. 1984. Primary structure homology between the product of the yeast cell division control gene CDC28 and vertebrate oncogenes. Nature 307: 183-185.

Masui, Y. and C.L. Markert. 1971. Cytoplasmic control of nuclear behavior during meiotic maturation of frog oocytes. $I$. Exp. Zool. 177: 129-146.

Meijer, L., D. Arion, R. Golsteyn, J. Pines, L. Brizuela, T. Hunt, and D. Beach. 1989. Cyclin is a component of the sea urchin egg M-phase specific histone $\mathrm{Hl}$ kinase. EMBO J. 8: 22752282.

Mendenhall, M.D., C.A. Jones, and S.I. Reed. 1987. Dual regulation of the yeast CDC28-p40 protein kinase complex: Cell cycle, pheromone, and nutrient limitation effects. Cell 50: $927-935$.

Mendenhall, M.D., H.E. Richardson, and S.I. Reed. 1988. Dominant negative protein kinase mutations that confer a G1 arrest phenotype. Proc. Natl. Acad. Sci. 85: 4426-4430.

Minshull, J., J.J. Blow, and T. Hunt. 1989. Translation of cyclin mRNA is necessary for extracts of activated Xenopus eggs to enter mitosis. Cell 56: 947-956.

Moreno, S., J. Hayles, and P. Nurse. 1989. Regulation of p34 cdc2 protein kinase during mitosis. Cell 58: 361-372.

Murray, A.W. and M.W. Kirschner. 1989a. Dominoes and clocks: The union of two views of the cell cycle. Science 246: 614-621.

. 1989b. Cyclin synthesis drives the early embryonic cell cycle. Nature 339: 275-280.

Murray, A.W., M.J. Solomon, and M.W. Kirschner. 1989. The role of cyclin synthesis in the control of maturation promoting factor activity. Nature 339: 280-286.

Nash, R., G. Tokiwa, S. Anand, K. Erickson, and A.B. Futcher. 1988. The $\mathrm{WHI1}^{+}$gene of Saccharomyces cerevisiae tethers cell division to cell size and is a cyclin homolog. EMBO $J$. 7: 4335-4346.

Nurse, P. and Y. Bissett. 1981. Gene required in G1 for commitment to cell cycle and in G2 for control of mitosis in fission yeast. Nature 292: 448-460.

O'Farrell, P.H., B.A. Edgar, D. Lakich, and C.F. Lehner. 1989. Directing cell division during development. Science 246: 635-640.

Okayama, H. and P. Berg. 1983. A cDNA cloning vector that permits expression of cDNA inserts in mammalian cells. Mol. Cell. Biol. 3: 280-289.
Pardee, A.B. 1989. G1 events and regulation of cell proliferation. Science 246: 603-608.

Pines, J. and T. Hunt. 1987. Molecular cloning and characterization of the mRNA for cyclin from sea urchin eggs. EMBO $I$. 6: 2987-2995.

Pines, J. and T. Hunter. 1989. Isolation of a human cyclin cDNA: Evidence for cyclin mRNA and protein regulation in the cell cycle and for interaction with $\mathrm{p} 34^{\text {cdc2 }}$. Cell 58: 833846.

Pondaven, P., L. Meijer, and D. Beach. 1990. Activation of Mphase-specific histone $\mathrm{H} 1$ kinase by modification of the phosphorylation of its p34 ${ }^{\text {cdc2 }}$ and cyclin components. Genes Dev. 4: 9-17.

Ponte, P., S.-Y. Ng, J. Engel, P. Gunning, and L. Kedes. 1984. Evolutionary conservation in the untranslated regions of actin mRNAs: DNA sequence of a human beta actin cDNA. Nucleic Acids Res. 12: 1687-1696.

Rao, P.N. and R.T. Johnson. 1970. Mammalian cell fusion: Studies on the regulation of DNA synthesis and mitosis. Nature 225: 159-164.

Reed, S.I. 1980. The selection of $S$. cerevisiae mutants defective in the start event of cell division. Genetics 95: 561-577.

Reed, S.I. and C. Wittenberg. 1990. A mitotic role for the Cdc28 protein kinase of S. cerevisiae. Proc. Natl. Acad. Sci. (in press).

Reed, S.I., J. Ferguson, and J.C. Groppe. 1982. Preliminary characterization of the transcriptional products of the Saccharomyces cerevisiae cell division cycle gene CDC28. Mol. Cell. Biol. 2: 412-425.

Reed, S.I., J.A. Hadwiger, and A. Lorincz. 1985. Protein kinase activity associated with the product of the yeast cell division cycle gene CDC28. Proc. Natl. Acad. Sci. 82: 40554059.

Reynhout, J.K. and L.D. Smith. 1974. Studies on the appearance and nature of a maturation-inducing factor in the cytoplasm of amphibian oocytes exposed to progesterone. Dev. Biol. 38: 394.

Riabowol, K., G. Draetta, L. Brizuela, D. Vandre, and D. Beach. 1989. The cdc2 kinase is a nuclear protein that is essential for mitosis in mammalian cells. Cell 57: 393-401.

Richardson, H.E., C. Wittenberg, F. Cross, and S.I. Reed. 1989. An essential G1 function for cyclin-like proteins in yeast. Cell 59: 1127-1133.

Rosenberg, A.H., B.N. Lade, D.S. Chui, S.W. Lin, J.J. Dunn, and F.W. Studier. 1987. Vectors for selective expression of cloned DNAs by T7 RNA polymerase. Gene 56: 125-135.

Rosenthal, E.T., T. Hunt, and J.V. Ruderman. 1980. Selective translation from RNA controls the pattern of protein synthesis during early development of the surf clam. Cell 20: $487-494$.

Rothstein, R.J. 1983. One-step gene disruption in yeast. Methods Enzymol. 101: 202-211.

Sadhu, K., S.I. Reed, H. Richardson, and P. Russell. 1990. cdc25Hs, a putative mitotic inducer gene in human cells, is predominantly expressed in G2. Proc. Nat1. Acad. Sci. (in press).

Saiki, R.K., D.H. Gelfand, S. Stoffel, S.J. Scharf, R. Higuchi, G.T. Horn, K.B. Mullis, and H.A. Erlich. 1988. Primer-directed enzymatic amplification of DNA with a thermostable DNA polymerase. Science 239: 487-491.

Sherman, F., G. Fink, and J.B. Hicks. 1982. Methods in yeast genetics. Cold Spring Harbor Laboratory Press, Cold Spring Harbor, New York.

Simanis, V. and P. Nurse. 1986. The cell cycle control gene $c d c 2^{+}$of fission yeast encodes a protein kinase potentially regulated by phosphorylation. Cell 45: 261-268. 
Smith, L.D. 1989. The induction of oocyte maturation: Transmembrane signalling events and regulation of the cell cycle. Development 107: 685-699.

Solomon, M., R. Booher, M. Kirschner, and D. Beach. 1988. Cyclin in fission yeast. Cell 54: 738-739.

Standart, N., J. Minshull, J. Pines, and T. Hunt. 1987. Cyclin synthesis, modification and destruction during meiotic maturation of the starfish oocyte. Dev. Biol. 124: 248-254.

Swenson, K.I., K.M. Farrell, and J.V. Ruderman. 1986. The clam embryo protein cyclin A induces entry into $M$-phase and the resumption of meiosis in Xenopus oocytes. Cell 47: 861870.

Westendorf, J.M., K.I. Swenson, and J.V. Ruderman. 1989. The role of cyclin B in meiosis I. J. Cell Biol. 108: 1431-1444.

Whitfield, W.G.F., C. Gonzalez, E. Sanchez-Herrero, and D.M. Glover. 1989. Transcripts of one of the two Drosophila cyclin genes become localised in pole cells during embryogenesis. Nature 338: 337-340.

Wittenberg, C. and S.I. Reed. 1988. Control of the yeast cell cycle is associated with assembly/disassembly of the Cdc28 protein kinase complex. Cell 54: 1061-1072.

Wittenberg, C., Sugimoto, K., and S.I. Reed. 1990. G1-specific cyclins of Saccharomyces cerevisiae: Cell cycle periodicity, regulation by mating pheromone and association with the p34 ${ }^{\text {Cdc28 }}$ protein kinase. Cell (in press). 


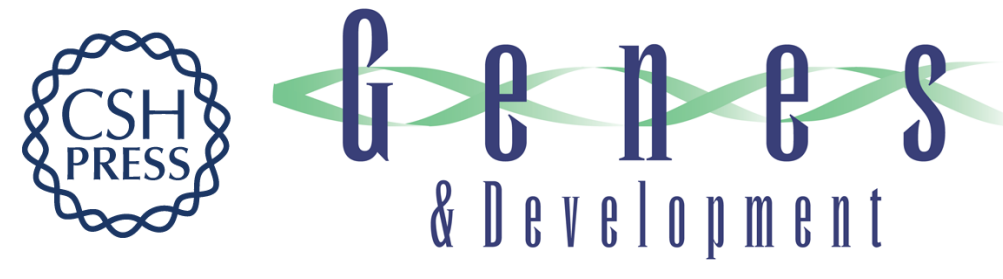

\section{Human cDNAs encoding homologs of the small p34Cdc28/Cdc2-associated protein of Saccharomyces cerevisiae and Schizosaccharomyces pombe.}

H E Richardson, C S Stueland, J Thomas, et al.

Genes Dev. 1990, 4:

Access the most recent version at doi:10.1101/gad.4.8.1332

References This article cites 84 articles, 23 of which can be accessed free at:

http://genesdev.cshlp.org/content/4/8/1332.full.html\#ref-list-1

License

Email Alerting Receive free email alerts when new articles cite this article - sign up in the box at the top

Service right corner of the article or click here.

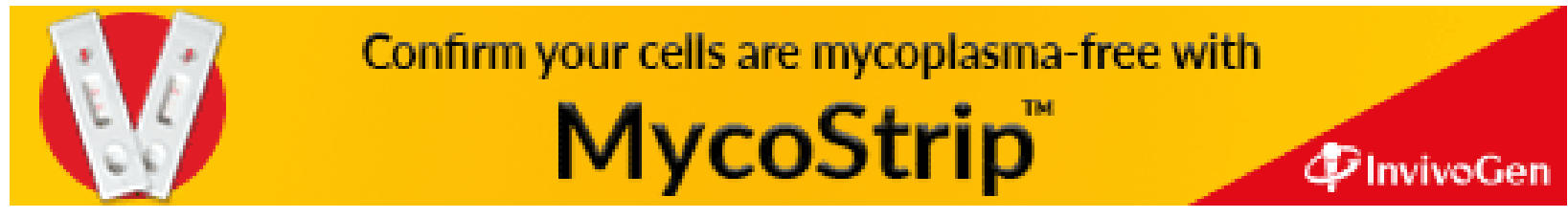

